\title{
Survival and Spread of Phytophthora capsici in Coastal Peru
}

\author{
O. Hurtado-Gonzáles, L. Aragon-Caballero, W. Apaza-Tapia, R. Donahoo, and K. Lamour
}

First, fourth, and fifth authors: University of Tennessee, Department of Entomology and Plant Pathology, Knoxville 37996; and second and third authors: Universidad Nacional Agraria La Molina, Departamento de Fitopatologia.

Accepted for publication 11 February 2008.

\begin{abstract}
Hurtado-Gonzales, O., Aragon-Caballero, L., Apaza-Tapia, W., Donahoo, R., and Lamour, K. 2008. Survival and spread of Phytophthora capsici in coastal Peru. Phytopathology 98:688-694.

Phytophthora capsici is a soilborne pathogen that causes significant losses to pepper production in Peru. Our objective was to investigate the mechanisms by which $P$. capsici is able to survive and spread. During 2005 to 2007, 227 isolates of $P$. capsici were collected from four species of pepper (Capsicum annum, C. baccatum, C. chinense, and C. pubescens) and tomato (Solanum lycopersicum) at 33 field sites in 13 provinces

amplified fragment length polymorphism (AFLP) analysis indicates that 221 of the isolates had the same genotype. Analyses of six polymorphic single nucleotide polymorphism (SNP) loci showed fixed heterozygosity suggesting a single clonal lineage is widely dispersed. Members of the same clonal lineage were recovered during 2005 to 2007 from geographically separate locations from each of the host types sampled. Our results indicate that clonal reproduction drives the population structure of $P$. capsici in Peru. The impact of continuous cropping and irrigation from common river sources on the population structure in Barranca Valley are discussed.
\end{abstract} across coastal Peru. All 227 isolates were of the A2 mating type and
Phytophthora capsici Leonian is a soilborne plant pathogen which causes fruit, crown, and root rot in a wide range of vegetable hosts including peppers, tomato, squash, melons, and most recently green and lima beans $(5,9,30,35,60)$. $P$. capsici was first described as a pathogen of pepper in New Mexico (42). Since the initial species description, $P$. capsici has been reported on additional hosts $(18,28,29,32-34,44,46,50,58,68,72)$. P. capsici can produce massive amounts of asexual deciduous sporangia on infected host and large scale epidemics can be initiated from a limited number of infected plants (62). Unlike many other Phytophthora diseases that are favored by cooler temperatures, disease is favored by warm $\left(25\right.$ to $\left.28^{\circ} \mathrm{C}\right)$ and wet conditions (9). $P$. capsici is heterothallic requiring the interaction of two mating types (A1 and A2) to complete the sexual stage and produce thick-walled sexual oospores. Oospores are capable of surviving in the soil for several years, germinating in favorable environmental conditions $(9,15,49,61)$. In the United States, both mating types are found at most locations and oospores are thought to play an important role in the epidemiology $(37-40,58)$. In addition, $P$. capsici has been isolated from creeks used for irrigation of vegetables in Michigan and it has been shown to infect diverse weeds $(16,19,56)$. In many cases crop rotation has not reduced the residual inoculum sufficiently to provide effective protection (41).

In Peru, $P$. capsici was first reported as the causal agent for wilt and root rot infecting several Capsicum spp. in 1971 (10). Since then, no other investigation has been conducted despite increasing losses due to $P$. capsici for pepper growers in Peru. Various practices are applied to control the epidemics, such as moderate irrigation, the use of well-drained fields, crop rotation, and fungicide treatments $(3,48)$. The Andean region of Peru-Bolivia is considered one of the centers of origin for species within the genus Capsicum. Archeological studies in coastal Peru have revealed evidence for the presence of Capsicum spp. dating back

Corresponding author: K. Lamour; E-mail address: klamour@utk.edu

doi:10.1094/PHYTO-98-6-0688

(c) 2008 The American Phytopathological Society
4,000 years (54). It is not known how long $P$. capsici has been present in and around the Capsicum center of origin, nor is it known whether $P$. capsici infected other ancient local crops, such as cucurbits, prior to Capsicum (6). Several varieties of $C$. annuum, as well as other species of Capsicum such as C. baccatum, $C$. chinense, and $C$. pubescens are cultivated across the coastal area of the country and several other Capsicum spp. are grown in the Amazon (55). Thus, a high diversity of the host may impact the pathogen population structure and evolution (73). A better understanding of the mechanisms by which $P$. capsici is surviving and spreading will assist in developing effective management and breeding strategies.

Our primary objective was to characterize the survival and spread of $P$. capsici in pepper production areas of coastal Peru. We report on the absence of diversity in $P$. capsici recovered from peppers and tomatoes from across coastal Peru for mating type, amplified fragment length polymorphism (AFLP), and single nucleotide polymorphism (SNP) markers, and we present a fine scale genotypic analysis of $P$. capsici recovered from pepper in the Barranca valley.

\section{MATERIALS AND METHODS}

Isolate recovery and sampling scheme. Samples collected in $2005(n=23)$ were received as standard diagnostic specimens and processed by the diagnostic clinic at the National Agricultural University, La Molina (Lima, Peru). Isolates were recovered from seven different hosts at 23 field sites (Fig. 1 and Table 1). During 2006 to 2007 a more intensive sampling was performed at 10 pepper fields located in Barranca, a coastal province $120 \mathrm{~m}$ north of the city of Lima. The fields spanned four districts: Barranca, Supe, Caral, and Minas (Fig. 2; Table 2). Fields were previously cultivated with the following hosts: tomato, potato, paprika, and/or artichoke. Fields varied in size from 3 to 10 ha and isolates were recovered from the following Capsicum species: C. annum, C. baccatum, C. chinense, and C. pubescens. Plants varied in age from 3 weeks-old to 3 months old and wilting was the primary symptom of infected plants. Adjacent plants within a field were avoided. All of the isolates were recovered from the crown region 
of infected plants. A minimum of 12 symptomatic plants were collected per field and transported to Lima for pathogen isolation at the diagnostic clinic (National Agricultural University, La Molina). P. capsici culture collection isolates CBS121656 (iso-

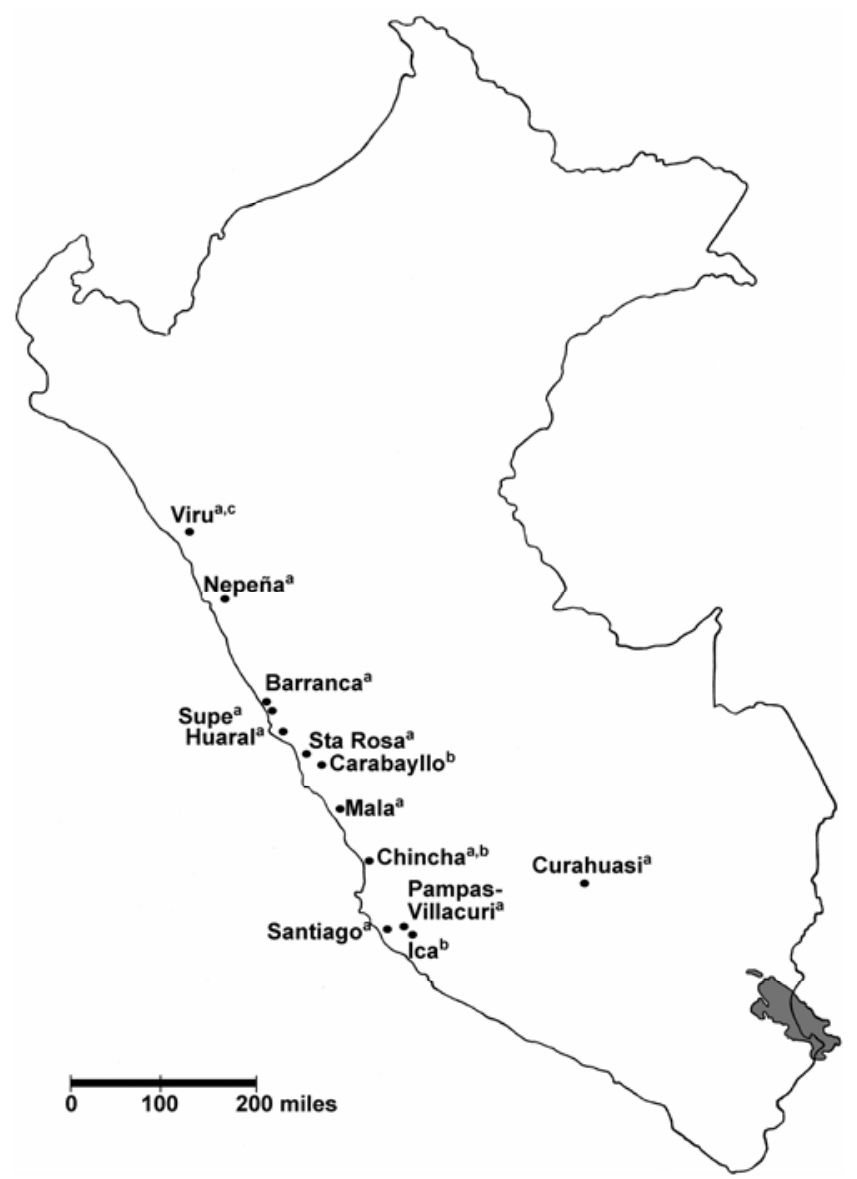

Fig. 1. Geographic locations for Phytophthora capsici isolates collected in Peru. Superscript $a$ following the location identifier indicates that isolates from clonal lineage PcPE-1 were present, $b$ indicates isolates from PcPE-2 were present, and $c$ indicates the location of LT2145. lated from infected cucumbers in Michigan 1997) and CBS121657 (isolated from infected pumpkins in Tennessee 2004) were also included in the study.

For pathogen isolation, infected plants were thoroughly washed with tap and sterile distilled water. Small sections of tissue were then excised from the edge of expanding lesion at the crown level and transferred to potato dextrose agar plates amended with PARP (100 ppm of pimaricin, $100 \mathrm{ppm}$ of ampicillin, $30 \mathrm{ppm}$ of rifampicin, and $100 \mathrm{ppm}$ of pentachloronitrobenzene). Plates were incubated for 2 days at room temperature. Hyphal tips were subcultured from actively expanding mycelium and transferred to V8-juice agar amended with PARP. For long-term storage, agar plugs of mycelium were stored in $2 \mathrm{ml}$ screw cap tubes with $1 \mathrm{ml}$ of sterile distilled water and three sterile hemp seeds.

To determine the mating type of $P$. capsici isolates, plugs of actively expanding mycelium were placed at the center of V8juice agar plates approximately $2 \mathrm{~cm}$ away from "tester" isolate CBS121656 (mating type A1) or CBS121657 (mating type A2). Plates were wrapped with Parafilm and incubated in the dark at room temperature for at least 1 week, after which observations were made for the production of oospores at the interface using a light microscope. Isolates able to produce oospores when crossed against CBS121656 were determined as A2 mating type. Conversely, isolates that were able to form oospores when crossed against CBS121657 were determined as A1 mating type.

DNA isolation and AFLP analyses. To determine genetic similarity among $P$. capsici isolates, AFLP profiles were generated for all 227 isolates. Isolates were grown and treated as previously described for DNA isolation (36). AFLP genotyping was done using EcoRI and MseI restriction endonucleases, adapters, and primers as described by Vos et al. (70). Preselective amplification was done using no selective nucleotides (Eco+0/ Mse+0) and selective amplification was conducted with selective primer pair (Eco+CG/Mse+CG). Selective amplifications were diluted and labeled in a separate reaction according to Habera et al. (25). AFLP fragments were resolved and analyzed on a CEQ 8000 Genetic Analysis System (Beckman Coulter) following the manufacturer's protocols. A 600 bp DNA size standard was used to resolve AFLP fragments (Beckman Coulter). AFLP marker sizes ranged from 70 to $500 \mathrm{bp}$. AFLP profiles were generated twice for each isolate using independent DNA extractions. A binary matrix was constructed using only clearly resolved,

TABLE 1. Phytophthora capsici isolates collected during 2005 from pepper and tomato in Peru

\begin{tabular}{|c|c|c|c|c|}
\hline Isolate & Isolation date & $\mathrm{MT}^{\mathrm{a}}$ & Origin (Province, State) & Host \\
\hline LT2135 & $01 / 24 / 05$ & A2 & Viru, La Libertad & Capsicum annum \\
\hline LT2136 & $01 / 25 / 05$ & A2 & Huaral, Lima & Solanum lycopersicum \\
\hline LT2137 & $01 / 25 / 05$ & $\mathrm{~A} 2$ & Carabayllo, Lima & Solanum lycopersicum \\
\hline LT2138 & $01 / 27 / 05$ & A2 & Huaral, Lima & Solanum lycopersicum \\
\hline LT2139 & $01 / 27 / 05$ & A2 & Santa Rosa Irrigation, Lima & Capsicum annum \\
\hline LT2140 & $02 / 02 / 05$ & A2 & Santiago Valley, Ica & Solanum lycopersicum \\
\hline LT2141 & $02 / 14 / 05$ & A2 & Santa Rosa Irrigation, Lima & Capsicum annum \\
\hline LT2142 & $03 / 08 / 05$ & A2 & Pampas de Villacuri, Ica & Capsicum annum \\
\hline LT2143 & $04 / 27 / 05$ & A2 & Nepeña, Ancash & Capsicum annum \\
\hline LT2144 & $05 / 04 / 05$ & A2 & Barranca, Lima & Capsicum chinense \\
\hline LT2145 & $05 / 10 / 05$ & A2 & Viru, La Libertad & Capsicum annum \\
\hline LT2146 & $05 / 12 / 05$ & A2 & Mala, Lima & Capsicum baccatum \\
\hline LT2147 & $05 / 12 / 05$ & A2 & Mala, Lima & Capsicum baccatum \\
\hline LT2148 & $05 / 31 / 05$ & A2 & Chincha, Ica & Capsicum annum \\
\hline LT2149 & $05 / 31 / 05$ & A2 & Chincha, Ica & Capsicum annum \\
\hline LT2150 & $08 / 17 / 05$ & A2 & Ica Valley, Ica & Capsicum annum \\
\hline LT2151 & $08 / 17 / 05$ & A2 & Ica Valley, Ica & Capsicum annum \\
\hline LT2152 & $09 / 07 / 05$ & A2 & Viru, La Libertad & Capsicum annum \\
\hline LT2153 & $10 / 23 / 05$ & A2 & Ica Valley, Ica & Solanum lycopersicum \\
\hline LT2847 & $06 / 27 / 05$ & A2 & Curahuasi, Abancay & Capsicum апnиит \\
\hline LT2848 & $06 / 27 / 05$ & A2 & Curahuasi, Abancay & Capsicum аппиит \\
\hline LT2849 & $06 / 27 / 05$ & A2 & Curahuasi, Abancay & Capsicum аппиит \\
\hline LT2850 & 09/19/05 & A2 & Supe, Lima & Capsicum аппиит \\
\hline
\end{tabular}

${ }^{\mathrm{a}} \mathrm{MT}=$ mating type. 
replicated markers. Using the program NTSYSpc 2.11a (Exeter Software, Setauket, NY), the combined data matrix was used to construct a genetic similarity matrix of all possible pairwise comparisons of individuals using Jaccard's similarity coefficient: $\mathrm{GS}(i j)=a /(a+b+c)$. GS $(i j)$ is the measure of genetic similarity between individuals $i$ and $j$, where $a$ is the number of polymorphic bands shared by $i$ and $j, b$ is the number of bands present in $i$ and absent in $j$, and $c$ is the number of bands present in $j$ but absent in $i$. A dendrogram constructed by employing an unweighted pair-group method with arithmetic average (UPGMA) cluster analysis. Bootstraps values were generated in phylogenetic analysis using parsimony (PAUP) version $4.0 \mathrm{~b} 10$ with 1,000 replicates (66).

SNP genotyping. Twenty isolates from the Barranca valley (2006 to 2007) and 23 isolates from the diagnostic clinic in 2005 were selected for subsequent analyses using six nuclear SNP

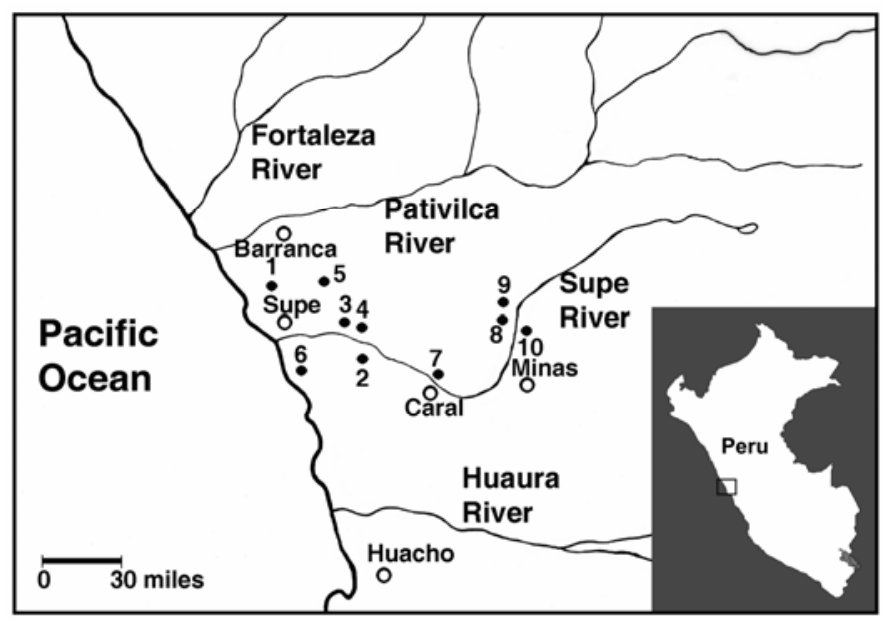

Fig. 2. Close-up depicting the location of 10 fields sampled in the Barranca Valley. Black circles indicate specific fields. markers (Table 3). The SNP markers were heterozygous in at least one of the samples tested. Custom TaqMan SNP Genotyping Assays (Foster City, CA) were designed according to the manufacturer's instructions (Table 3). SNP assays were performed using $7.5 \mu \mathrm{l}$ of iQ Supermix (Bio-Rad), $0.325 \mu \mathrm{l}$ of Taqman probe/primers allelic discrimination cocktail (40x), $2 \mu$ l of DNA $(\approx 15$ to $20 \eta \mathrm{g})$ and $3.2 \mu \mathrm{l}$ of molecular biology grade $\mathrm{H}_{2} \mathrm{O}$. Polymerase chain reactions (PCR) were carried out in 96-well plates (Bio-Rad) in triplicates for each isolate on an $\mathrm{iQ5}$ real-time thermal cycler (Bio-Rad) using the following parameters: $95^{\circ} \mathrm{C}$ for $10 \mathrm{~min}, 40$ cycles of $92^{\circ} \mathrm{C}$ for $15 \mathrm{~s}$ and $60^{\circ} \mathrm{C}$ for $1 \mathrm{~min}$. Each assay was standardized for their optimal cycling PCR conditions. Results were analyzed with the accompanying iQ5 optical system software 1.0 (Bio-Rad) using the allelic discrimination option, adjusting parameters for cycle threshold $(\mathrm{Ct})$ values and relative fluorescent units (RFU) according to the manufacturer's instructions. Results were scored as allele $1=11$ (FAM), allele $2=22$ (VIC), and heterozygous $=12$. A concatenated similarity tree with bootstraps (AFLP and SNP) was built as described above.

\section{RESULTS}

AFLP genotyping and mating type. AFLP using the Eco+CG/ $\mathrm{Mse}+\mathrm{CG}$ primer pair generated 50 reproducible markers. Four of the 50 alleles identified were only found in the United State's isolates (CBS121656 and CBS1211657). Isolates recovered from the Barranca valley in $2005(n=2)$ and 2006 to $2007(n=204$, represented by isolate LT3738) were found to exhibit a single AFLP genotype with 35 AFLP markers. Seventeen of the twentythree isolates submitted to the clinic in 2005 had the LT3738 genotype. Of the remaining clinic isolates, all except one had a different AFLP genotype composed of 45 AFLP markers (represented by isolate LT2137). Representative isolates LT3738 and LT2137 had 34 AFLP markers in common. The last isolate (LT2145) had a unique AFLP genotype consisting of 37 AFLP markers. AFLP genotypes LT3738 and LT2137 were identified as clonal types and are referred to as PcPE-1 and PcPE-2.

TABLE 2. Phytophthora capsici isolates collected from peppers at 10 locations in Lima, Barranca province, in 2006 to 2007

\begin{tabular}{|c|c|c|c|c|}
\hline Field & No. of isolates & Year & Origin & Host \\
\hline 1 & 19 & 2006 & Barranca, Lima & Capsicum pubescens \\
\hline 2 & 18 & 2006 & Supe, Lima & Capsicum chinense \\
\hline 3 & 12 & 2006 & Supe, Lima & C. baccatum var. pendulum \\
\hline 4 & 13 & 2006 & Supe, Lima & C. baccatum var. pendulum \\
\hline 5 & 18 & 2006 & Barranca, Lima & Capsicum annum \\
\hline 6 & 36 & 2006 & Barranca, Lima & Capsicum annum \\
\hline 7 & 36 & 2007 & Caral, Lima & Capsicum annum \\
\hline 8 & 18 & 2007 & Minas, Lima & Capsicum annum \\
\hline 9 & 14 & 2007 & Minas, Lima & Capsicum annum \\
\hline 10 & 20 & 2007 & Minas, Lima & Capsicum annum \\
\hline
\end{tabular}

TABLE 3. Primers and probe sequences used for single nucleotide polymorphism (SNP) genotyping with Taqman assays ${ }^{\text {a }}$

\begin{tabular}{|c|c|c|c|}
\hline Locus name & Primer sequence & $\begin{array}{l}\text { Internal reporter oligonucleotide } \\
\text { (probe) VIC }\end{array}$ & $\begin{array}{l}\text { Internal reporter oligonucleotide } \\
\text { (probe) FAM }\end{array}$ \\
\hline \multirow[t]{2}{*}{ SNP11 } & F_5'-AGATTGAGAAGAAGGAACTTGGTCATG-3' & & \\
\hline & R_5'-CCTTCTCACCTGTAACCTTGCTAAT-3' & 5'-ACGCACAGTGCCGTAG-3' & 5'-ACGCACAGTACCGTAG-3' \\
\hline \multirow[t]{2}{*}{ SNP14 } & F_5'-CGCTGTGTCGATAGTGGGAATG-3' & & \\
\hline & R_5'-TCTTCTCTCTGTGTTCGACTACCA-3' & 5'-CTTGAGCTㅆAATTCTCT-3' & 5'-TTGAGCTCEATTCTCT-3' \\
\hline \multirow[t]{2}{*}{ SNP15 } & F_5'-TTCCGACGAGCAACGAACA-3' & & \\
\hline & R_5'-GTACCGTGCCACGCAGAT-3' & 5'-TCTTGCATACÂTTCTGG-3' & 5'-TCTTGCATACGTTCTGG-3' \\
\hline \multirow[t]{2}{*}{ SNP16 } & F_5'-GCCAGCATGCTCGATATTGG-3' & & \\
\hline & R_5'-GCAGTCAGGGCCAAGCA-3' & 5'-CAATTGCAACA-AGGCAA-3' & 5'-CCAATTGCAACIAGGCAA-3' \\
\hline \multirow[t]{2}{*}{ SNP20 } & F_5'-CCACTCGGCCGACAACTC-3' & & \\
\hline & R_5'-GATGATGCTAAGATCGTACCAAAGC-3' & 5'-TACTCTGGGTGGAAATG-3' & 5'-CTACTCTÁGTGGAAATG-3' \\
\hline \multirow[t]{2}{*}{ URA3 } & F_5'-CGAAGGACAACGCGAACTTG-3' & & \\
\hline & R_5'-CTGCGTGACGCCATCAAC-3' & 5'-TGCTGCGTCGACTG-3' & 5'-TGCTGCA \\
\hline
\end{tabular}

a Underlined nucleotide refers to the assessed SNP. $\mathrm{F}=$ forward and $\mathrm{R}=$ reverse. 
Isolates belonging to the clonal lineage PcPE-1 were recovered from widely dispersed geographic fields (e.g., Ica and Trujillo, Fig. 1) whereas isolates from PcPE-2 were confined to Lima and Ica (Fig. 1). Mating type analysis revealed that all 227 isolates were the A2 mating type.

SNP and genotyping. Analysis of six SNP markers showed a strong correlation with the AFLP analysis. Thirty-four of the thirty-seven isolates identified as the PcPE-1 type using AFLP had SNP profiles identical to PcPE-1, five isolates with the PcPE-

TABLE 4. Summary of single nucleotide polymorphism (SNP) multilocus genotypes for 43 representative isolates of the PcPE- 1 and PcPE- 2 clonal lineages and the unique isolate LT2145

\begin{tabular}{|c|c|c|c|c|c|}
\hline \multirow{3}{*}{$\begin{array}{l}\text { Locus name/ } \\
\text { isolate ID }\end{array}$} & \multicolumn{5}{|c|}{ Clonal lineage } \\
\hline & \multicolumn{3}{|c|}{ PcPE-1 } & \multirow{2}{*}{$\frac{\text { PcPE-2 }}{\text { LT2137 }}$} & \multirow{2}{*}{$\begin{array}{c}\text { Unique isolate } \\
\text { LT2145 }\end{array}$} \\
\hline & LT3738 & LT3726 & LT3753 & & \\
\hline SNP11 & $\mathrm{A} / \mathrm{A}$ & $\mathrm{A} / \mathrm{A}$ & $\mathrm{A} / \mathrm{A}$ & G/A & G/A \\
\hline SNP14 & $\mathrm{A} / \mathrm{A}$ & $\mathrm{A} / \mathrm{A}$ & $\mathrm{A} / \mathrm{A}$ & $\mathrm{A} / \mathrm{C}$ & $\mathrm{A} / \mathrm{C}$ \\
\hline SNP15 & $\mathrm{A} / \mathrm{G}$ & $\mathrm{A} / \mathrm{A}$ & $\mathrm{A} / \mathrm{A}$ & $\mathrm{A} / \mathrm{A}$ & $\mathrm{A} / \mathrm{G}$ \\
\hline SNP16 & $\mathrm{A} / \mathrm{T}$ & $\mathrm{A} / \mathrm{T}$ & $\mathrm{A} / \mathrm{T}$ & $\mathrm{A} / \mathrm{T}$ & $\mathrm{T} / \mathrm{T}$ \\
\hline SNP20 & $\mathrm{A} / \mathrm{G}$ & $\mathrm{A} / \mathrm{G}$ & $\mathrm{A} / \mathrm{G}$ & $\mathrm{A} / \mathrm{G}$ & $\mathrm{A} / \mathrm{A}$ \\
\hline URA3 & $\mathrm{A} / \mathrm{G}$ & $\mathrm{A} / \mathrm{G}$ & G/G & $\mathrm{A} / \mathrm{G}$ & $\mathrm{A} / \mathrm{G}$ \\
\hline Genotype & 0.79 & 0.05 & 0.02 & 0.12 & 0.02 \\
\hline frequency ${ }^{\mathrm{a}}$ & $\mathrm{N}=34$ & $\mathrm{~N}=2$ & $\mathrm{~N}=1$ & $\mathrm{~N}=5$ & $\mathrm{~N}=1$ \\
\hline
\end{tabular}

a $\mathrm{N}$ represents the number of isolates identified with a particular SNP genotype configuration.
2 AFLP profile had SNP profiles identical to PcPE-2, and LT2145, which had a unique AFLP profile, also had a unique multi-locus SNP profile (Table 4). Two isolates identified as the PcPE-1 type using AFLP (LT3726 and LT3762) had a single SNP marker, SNP 15, changed from AG to AA (Table 4). Additionally, LT3753, identified as PcPE-1 with AFLP, had two SNP markers changed from hetero- to homozygosity; URA3 changed from AG to GG, and SNP 15 changed from AG to AA (Table 4). Clone correction of the 227 isolates reduced the total number of unique multi-locus genotypes to five, and for all six SNP markers, only two of the three possible genotypes were observed. Due to the small size of the clone corrected data set, Hardy-Weinberg and other population genetic metrics that are based on allele frequencies were not calculated. A UPGMA cluster analysis combining AFLP and SNP markers revealed that the two distinct clusters (PcPE-1 and PcPE-2) shared approximately $70 \%$ of the markers (Fig. 3).

\section{DISCUSSION}

This is the first large-scale spatiotemporal population study of $P$. capsici infecting peppers and tomatoes in Peru using molecular tools. P. capsici is a major biological threat to peppers in Peru and our objective was to better understand how $P$. capsici is surviving and spreading. There are few population studies characterizing the genotypic diversity of $P$. capsici outside of the United States, and a limited number of studies indicating the frequency of the

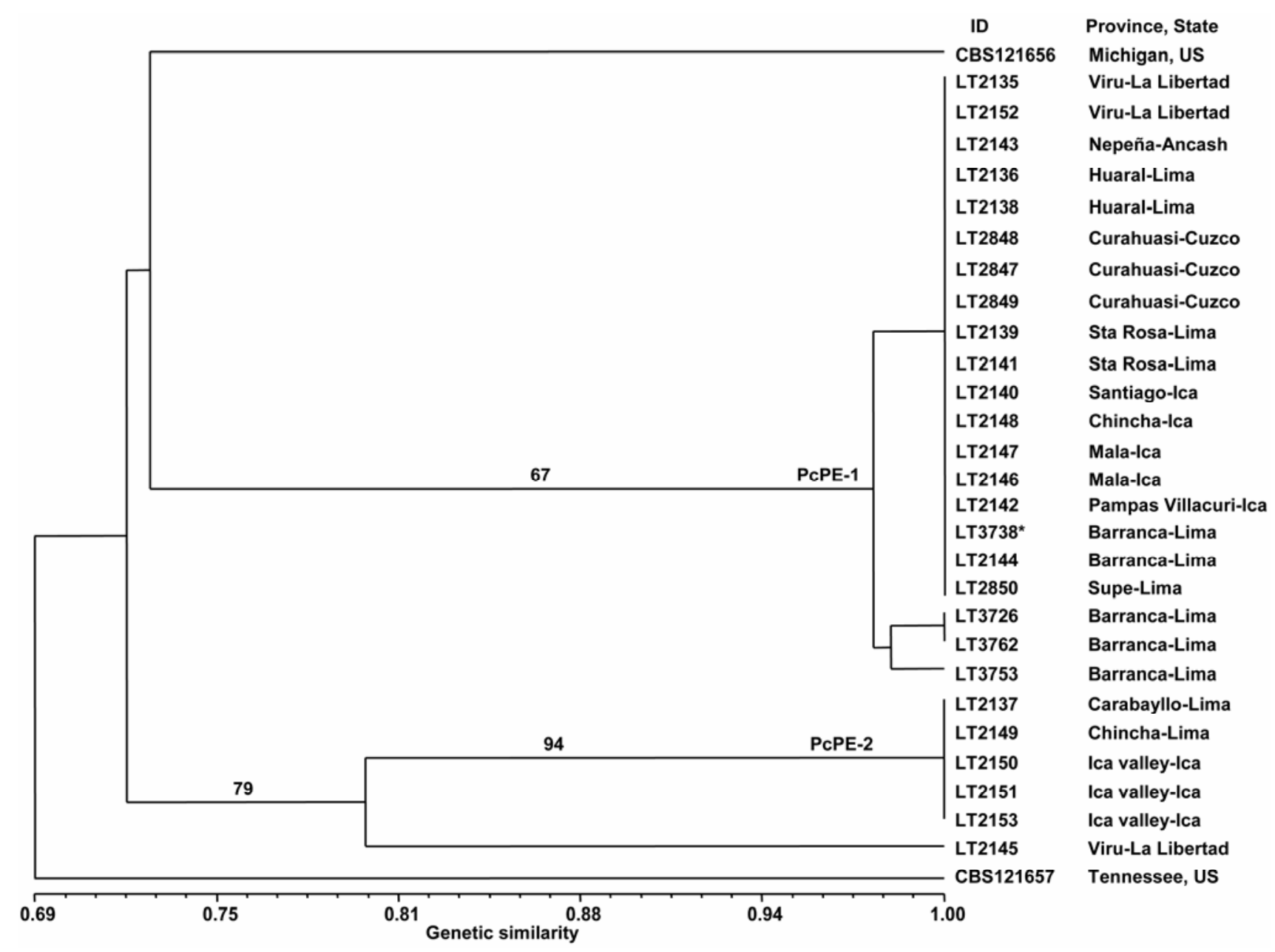

Fig. 3. Unweighted pair-group method with arithmetic average cluster analysis of Phytophthora capsici isolates from 13 provinces across Peru during 2005 to 2007 using 50 amplified fragment length polymorphism markers (AFLP) and six single nucleotide polymorphism (SNP) loci. LT3738* represents 200 P. capsici isolates with identical AFLP profiles from Barranca province in Lima from 2006 to 2007. LT number refers to isolate identification for isolates that have not been deposited into a collection. Bootstrap values are based on 1,000 replicates and the major clonal lineages are indicated by the designators PcPE-1 and PcPE-2. 
A1 or A2 mating types at specific sites. In Northwest Spain, 16 isolates from 11 locations had a low level of genetic variation based on random amplified polymorphism DNA (RAPD) analysis and all were a single (A1) mating type (63). Additional reports of only a single mating type include reports from Bulgaria (45 isolates, all A1), southern Italy (60 isolates, all A2), and southeastern Spain (3 isolates, all A1) $(27,31,52)$. Both mating types have been reported from Brazil, Canada, Mexico, and northern Italy $(1,12,45,67)$.

AFLP and SNP analysis of 227 P. capsici isolates recovered from 2005 to 2007 from four different Capsicum spp. and tomato at 33 locations throughout Peru revealed a surprisingly homogenous population with much lower genotypic and overall genetic diversity compared to populations analyzed in the United States $(26,38,39)$. A single clonal lineage (PcPE-1) accounts for 221 of the isolates and this clonal type was recovered in all of the locations sampled except for three isolates from the Ica Valley (Figs. 1 and 3). Also surprising, but consistent with the molecular data, was the finding that all of the isolates had the A2 mating type. For the United State's populations that have been analyzed in detail, the overall picture is significantly different. In the United States, both the A1 and A2 mating types have been recovered from many different locations and the genetic structure clearly reflects the impact of sexual recombination on the overall population biology $(4,11,26,29,33,37,39,41,51,58)$. In Michigan, the expansion of clonal lineages is common within single fields during a single year; but spread of clonal lineages over long distances or survival over the winter has not been detected $(40,41)$.

Although AFLP data showed no new AFLP genotypes in the Barranca valley from 2005 to 2007, SNP genotyping of a subset of isolates revealed changes from heterozygosity to homozygosity at two loci; SNP15 and URA3 (Table 4). Since the overall AFLP profile is identical to the PcPE-1 clonal type there is no evidence that sex has occurred and most likely these changes are due to some kind of mitotic effect (e.g., gene conversion) (20). Mitotic recombination as well as mutation and gene conversion are thought to be sources of variation for Phytophthora spp. that spread as large clonal lineages such as $P$. infestans, $P$. cinnamomi, and $P$. ramorum $(7,21,57)$.

Currently it is not clear how a single clonal lineage has spread throughout coastal Peru. In the United States, $P$. capsici does not appear to be spread long distances aerially similar to $P$. infestans and movement is most likely via infested water, soil, or plant parts (59). The finding of a limited number of widely dispersed clonal lineages parallels the situation with $P$. infestans in Peru where clonal lineages define the population structure. For both $P$. capsici and $P$. infestans migration of the opposite mating type (A1 for $P$. capsici and A2 for $P$. infestans) could significantly impact the overall diversity of populations and may contribute to increased crop losses and pathogen survival $(2,8,13,14,17,21-$ 24,53,64,65,69).

Coastal Peru is a very dry agricultural system with very little annual rainfall (less than $50 \mathrm{~mm} /$ year) and above-ground infection and sporulation is generally not observed. The geography at many of the sites sampled precludes infested irrigation water accounting for the observed population structure as they are separate valleys and rely on separate water sources. Further investigations of movement on seedlings and/or seed are warranted. For the isolates collected from the ten fields in the Barranca valley the situation may be easier to explain. The pepper cropping season in the Barranca coastal areas starts in October and plants are mature in April. Further up the valley, at a higher elevation (Caral and Minas districts), the climate allows and farmers practice yearround pepper cultivation. Irrigation water in the Barranca valley comes from the Supe River, which runs west from the slope Andean mountains to the Pacific Ocean (Fig. 2) and it is possible that $P$. capsici outbreaks occurring in higher areas of the valley contribute to the incidence of pepper root rot and crown rot in lower parts of the valley. In addition, alternative explanations such as movement of plant seedling, tools, and survival of latent mycelium or sporangia in plant debris should not be excluded. Current methods to control $P$. capsici include avoiding excess water in the plant rhizosphere through conservative irrigation and planting on raised beds. Drip irrigation is employed in some cases, but not all farmers have access to this technology. In light of our findings it will be important to test the above-ground irrigation water for the presence of $P$. capsici.

Peppers, originally cultivated in South America, now have more than five cultivated species and over twenty wild species (27). Archeological studies revealed deposits of cultivated types of Capsicum baccatum dating back 4,000 years in coastal areas in Peru (54) and a major portion of Capsicum evolution appears to have occurred in the south-central Peruvian and Bolivian Andes (43). Our studies suggests that P. capsici in Peru has the profile of an introduced pathogen. Additional investigation into the population structure of $P$. capsici at other locations in Peru (e.g., $C$. pubescences cultivated in the Amazon, in the eastern side of the Andes) and other areas in South America may provide some clues to the current situation and may help identify current and past possible routes of dissemination.

Breeding for resistance against $P$. capsici has been challenging due to the high diversity of pathogen populations in the United States $(47,71)$. If the genotypic clonality of $P$. capsici in Peru is reflective of fewer race types of $P$. capsici, then this could offer the advantage for pepper breeders to generate resistant pepper lines that protect against one or a few clonal lineages. In light of the mitotic genetic changes that may be occurring within the context of a clonal population, it will be important to include a panel of clonal isolates from different geographic locations in the screening program.

\section{LITERATURE CITED}

1. Anderson, T. R., and Garton, R. 2000. First report of blight of field peppers caused by Phytophthora capsici in Ontario. Plant Dis. 84:705705 .

2. Andrivon, D. 1996. The origin of Phytophthora infestans populations present in Europe in the 1840s: A critical review of historical and scientific evidence. Plant Pathol. 45:1027-1035.

3. Apaza, W., Quino, Y., Negishi, H., and Suyama, K. 2005. Control of Phytophthora capsici in pepper (Capsicum annuum Leon) with Trichoderma viride in different substrates. J. ISSAAS 11:71-78.

4. Biles, C. L., Liddell, C. M., and Faubion, G. F. 1991. Phytophthora capsici strain characterization in southern New Mexico. Phytopathology 81:1192.

5. Davidson, C. R., Carroll, R. B., Evans, T. A., Mulrooney, R. P., and Kim, S. H. 2002. First report of Phytophthora capsici infecting lima bean (Phaseolus lunatus) in the Mid-Atlantic Region. Plant Dis. 86:1049-1049.

6. Dillehay, T. D., Rossen, J., Andres, T. C., and Williams, D. E. 2007. Preceramic adoption of peanut, squash, and cotton in northern Peru. Science 316:1890-1893.

7. Dobrowolski, M. P., Tommerup, I. C., Shearer, B. L., and O’Brien, P. A. 2003. Three clonal lineages of Phytophthora cinnamomi in Australia revealed by microsatellites. Phytopathology 93:695-704.

8. Drenth, A., Tas, I. C. Q., and Govers, F. 1994. DNA fingerprinting uncovers a new sexually reproducing population of Phytophthora infestans in the Netherlands. Eur. J. Plant Pathol. 100:97-107.

9. Erwin, D. C., and Ribeiro, O. K. 1996. Phytophthora Diseases Worldwide. American Phytopathological Society, St. Paul, MN.

10. Fernandez-Northcote, E. N. 1971. La marchitez y otras enfermades de Capsicum spp cultivadas en el Peru. Paper read at Primer Congreso Nacional de Investigadores Agricolas y Pecuarios del Peru, at Lima, Peru.

11. Fernandez-Pavia, S. P., Biles, C. L., Waugh, M. E., Onsurez, W., Rodriguez-Alvarado, G., and Liddell, C. M. 2004. Characterization of southern New Mexico Phytophthora capsici Leonian isolates from pepper (Capsicum annuum L.). Rev. Mexicana de Fitopatol. 22:82-89.

12. Fernandez-Pavia, S. P., Rodriguez-Alvarado, G., and Sanchez-Yanez, J. M. 2003. Buckeye Rot of tomato caused by Phytophthora capsici in Michoacan, Mexico. Plant Dis. 87:872-872.

13. Flier, W. G., Grunwald, N. J., Kroon, L. P. N. M., Sturbaum, A. K., van den Bosch, T. B. M., Garay-Serrano, E., Lozoya-Saldana, H., Fry, W. E., 
and Turkensteen, L. J. 2003. The population structure of Phytophthora infestans from the Toluca valley of central Mexico suggests genetic differentiation between populations from cultivated potato and wild Solanum spp. Phytopathology 93:382-390.

14. Forbes, G. A., Escobar, X. C., Ayala, C. C., Revelo, J., Ordonez, M. E., Fry, B. A., Doucett, K., and Fry, W. E. 1997. Population genetic structure of Phytophthora infestans in Ecuador. Phytopathology 87:375-380.

15. French-Monar, R. D., Jones, J. B., Ozores-Hampton, M., and Roberts, P. D. 2007. Survival of inoculum of Phytophthora capsici in soil through time under different soil treatments. Plant Dis. 91:593-598.

16. French-Monar, R. D., Jones, J. B., and Roberts, P. D. 2006. Characterization of Phytophthora capsici associated with roots of weeds on Florida vegetable farms. Plant Dis. 90:345-350.

17. Fry, W. E., Goodwin, S. B., Dyer, A. T., Matsuzak, J. M., Drenth, A., Tooley, P. W., Sujkowski, L. S., Koh, Y. J., Cohen, B. A., Spielman, L. J., Deahl, K. L., Inglis, D. A., and Sandlan, K. P. 1993. Historical and recent migrations of Phytophthora infestans: Chronology, pathways, and implications. Plant Dis. 77:653-661.

18. Galindo, J., and Zentmyer, G. A. 1967. Genetical and cytological studies of Phytophthora strain pathogenic to pepper plants. Phytopathology 57:1300-1304

19. Gevens, A., Donahoo, R. S., Lamour, K. H., and Hausbeck, M. K. 2006. Baiting Phytophthora capsici from Michigan surface irrigation water and characterization of isolates. Phytopathology 97:421-428.

20. Goodwin, S. B. 1997. The population genetics of Phytophthora. Phytopathology 87:462-473.

21. Goodwin, S. B., Cohen, B. A., and Fry, W. E. 1994. Panglobal distribution of a single clonal lineage of the Irish potato famine fungus. Proc. Natl. Acad. Sci. USA 91:11591-11595.

22. Goodwin, S. B., Sujkowski, L. S., Dyer, A. T., Fry, B. A., and Fry, W. E. 1995. Direct detection of gene flow and probable sexual reproduction of Phytophthora infestans in northern North America. Phytopathology 85:473-479.

23. Goodwin, S. B., Sujkowski, L. S., and Fry, W. E. 1996. Rapid evolution of pathogenicity within clonal lineages of the potato late blight disease fungus. Phytopathology 85:669-676.

24. Grunwald, N. J., Flier, W. G., Sturbaum, A. K., Garay-Serrano, E., van den Bosch, T. B. M., Smart, C. D., Matuszak, J. M., Lozoya-Saldana, H., Turkensteen, L. J., and Fry, W. E. 2001. Population structure of Phytophthora infestans in the Toluca valley region of central Mexico. Phytopathology 91:882-890.

25. Habera, L., Smith, N., Donahoo, R., and Lamour, K. H. 2004. Use of a single primer to fluorescently label selective amplified fragment length polymorphism reactions. Biotechniques 37:902-904.

26. Hausbeck, M. K., and Lamour, K. H. 2004. Phytophthora capsici on vegetable crops: Research progress and management challenges. Plant Dis. $88: 1292-1303$

27. Heiser, C. B., and Smith, P. G. 1953. The cultivated Capsicum pepper. Econ. Bot. 7:214-227.

28. Herrero, M. L., Blanco, R., Santos, M., and Tello, J. C. 2002. First report of Phytophthora capsici on cucumber and melon in southeastern Spain. Plant Dis. 86:558.

29. Hwang, B. K., de Cock, A. M., Bahnweg, G., Prell, H., and Heitefuss, R. 1991. Restriction fragment length polymorphisms of mitochondrial DNA among Phytophthora capsici isolates from pepper (Capsicum annum). Syst. Appl. Microbiol. 14:111-116.

30. Hwang, B. K., and Kim, C. H. 1995. Phytophthora blight of pepper and its control in Korea. Plant Dis. 79:221-227.

31. Ilieva, S., and Vintanov, M. 1980. Cultural, morphological and physiological characteristics of Phytophthora capsici in sweet peppers. Gradinarska-i-Lozarska-Nauka 17:61-68.

32. Isakeit, T. 2007. Phytophthora Blight caused by Phytophthora capsici on pumpkin and winter squash in Texas. Plant Dis. 91:633-633.

33. Islam, S. Z., Babadoost, M., Lambert, K. N., Ndeme, A., and Fouly, H. M. 2005. Characterization of Phytophthora capsici isolates from processing pumpkin in Illinois. Plant Dis. 89:191-197.

34. Kreutzer, W. A. 1937. Phytophthora rot of cucumber fruit. Phytopathology 27:955.

35. Kreutzer, W. A., Bodine, E. W., and Durrell, L. W. 1940. Cucurbit diseases and rot of tomato fruit caused by Phytophthora capsici. Phytopathology 30:972-976.

36. Lamour, K. H., and Finley, L. 2006. A strategy for recovering high quality genomic DNA from a large number of Phytophthora isolates. Mycologia 98:514-517.

37. Lamour, K. H., and Hausbeck, M. K. 2000. Mefenoxam insensitivity and the sexual stage of Phytophthora capsici in Michigan cucurbit fields. Phytopathology 90:396-400.

38. Lamour, K. H., and Hausbeck, M. K. 2001. The dynamics of mefenoxam insensitivity in a recombining population of Phytophthora capsici characterized with amplified fragment length polymorphism markers.
Phytopathology 91:553-557.

39. Lamour, K. H., and Hausbeck, M. K. 2001. Investigating the spatiotemporal genetic structure of Phytophthora capsici in Michigan. Phytopathology 91:973-980.

40. Lamour, K. H., and Hausbeck, M. K. 2002. The spatiotemporal genetic structure of Phytophthora capsici in Michigan and implications for disease management. Phytopathology 92:681-684.

41. Lamour, K. H., and Hausbeck, M. K. 2003. Effect of crop rotation on the survival of Phytophthora capsici and sensitivity to mefenoxam. Plant Dis. 87:841-845.

42. Leonian, L. H. 1922. Stem and fruit blight of peppers caused by Phytophthora capsici sp. nov. Phytopathology 12:401-408.

43. MacLeod, M. J., Eshbaugh, W. H., and Guttman, S. I. 1979. A preliminary biochemical systematic study of the genus Capsicum-Solanaceae. Pages 701-714 in: The Biology and Taxonomy of the Solanaceae. J. G. Hawkes, R. N. Lester, and A. D. Skelding, eds. Academic Press, New York.

44. Marque, J. M., de Souza, N. L., and Cutolo-Filho, A. A. 2004. Mating type, mycelium growth and sporulation of Phytophthora capsici isolates obtained from pepper. Summa Phytopathol. 30:389-390.

45. Matsuoka, K., Luz, E. D. M. N., Faleiro, F. G., Cerqueira, A. O., Dantas, N. A., and Marques, J. R. B. 2003. Genetic diversity of Phytophthora capsici isolates from different hosts based on RAPD markers, pathogenicity and morphology. Fitopatol. Bras. 28:559-564.

46. Miller, S. A., Bhat, R. G., and Schmitthenner, A. F. 1994. Detection of Phytophthora capsici in pepper and cucurbit crops in Ohio with two commercial immunoassay kits. Plant Dis. 78:1042-1046.

47. Oelke, L. M., Bosland, P. W., and Steiner, R. 2003. Differentiation of race specific resistance to Phytophthora root rot and foliar blight in Capsicum апnиит. J. Am. Soc. Hortic. Sci. 128:213-218.

48. Pantoja-Garcia, N. R. 1994. Phytophthora capsici L.: Cultural and morphological characteristics on three commercial varieties of Capsicum and its chemical control using Trichoderma viride Pers. M.Sc., Plant Pathology, National Agricultural University, La Molina, Lima.

49. Papavizas, G. C., Bowers, J. H., and Johnston, S. A. 1981. Selective isolation of Phytophthora capsici from soils. Phytopathology 71:129-133.

50. Parra, G., and Ristaino, J. B. 1998. Insensitivity to Ridomil Gold (mefenoxam) found among field isolates of Phytophthora capsici causing Phytophthora blight on bell pepper in North Carolina and New Jersey. Plant Dis. 82:711.

51. Parra, G., and Ristaino, J. B. 2001. Resistance to mefenoxam and metalaxyl among field isolates of Phytophthora capsici causing Phytophthora blight of bell pepper. Plant Dis. 85:1069-1075.

52. Pennisi, A. M., and Agosteo, G. 1998. Insensitivity to metalaxyl among isolates of Phytophthora capsici causing root and crown rot of pepper in southern Italy. Plant Dis. 82:1283.

53. Perez, W. G., Gamboa, J. S., Falcon, Y. V., Coca, M., Raymundo, R. M., and Nelson, R. J. 2001. Genetic structure of Peruvian populations of Phytophthora infestans. Phytopathology 91:956-965.

54. Pickersgill, B. 1969. The archaeological record of chili peppers (Capsicum spp.) and the sequence of plant domestication in Peru. Am. Antiquity 34:54-61.

55. Pickersgill, B. 1969. The domestication of chili peppers. Pages 443 446 in: The Domestication and Exploitation of Plants and Animals. P. J. Ucko and G. W. Dimbleby, eds. Aldine Publishing Company, Chicago, IL

56. Ploetz, R. C., Heine, G., Haynes, J., and Watson, M. 2002. An investigation of biological attributes that may contribute to the importance of Phytophthora capsici as a vegetable pathogen in Florida. Ann. Appl. Biol. 140:61-67.

57. Prospero, S., Hansen, E. M., Grunwald, N. J., and Winton, L. M. 2007. Population dynamics of the sudden oak death pathogen Phytophthora ramorum in Oregon from 2001 to 2004. Mol. Ecol. 16:2958-2973.

58. Ristaino, J. B. 1990. Intraspecific variation among isolates of Phytophthora capsici from pepper and cucurbit fields in North Carolina. Phytopathology 80:1253-1259.

59. Ristaino, J. B., and Gumpertz, M. L. 2000. New frontiers in the study of dispersal and spatial analysis of epidemics caused by species in the genus Phytophthora. Annu. Rev. Phytopathol. 38:541-576.

60. Satour, M. M., and Butler, E. E. 1967. A root and crown rot of tomato caused by Phytophthora capsici and P. parasitica. Phytopathology 57:510-515.

61. Satour, M. M., and Butler, E. E. 1968. Comparative morphological and physiological studies of the progenies from intraspecific matings of Phytophthora capsici. Phytopathology 58:183-192.

62. Schlub, R. L. 1983. Epidemiology of Phytophthora capsici on bell pepper. J. Agric. Sci. Camb. 100:7-11

63. Silvar, C., Merino, F., and Diaz, J. 2006. Diversity of Phytophthora capsici in northwest Spain: Analysis of virulence, metalaxyl response, and molecular characterization. Plant Dis. 90:1135-1142. 
64. Spielman, L. J., Drenth, A., Davidse, L. C., Sujkowski, L. J., Gu, W., Tooley, P. W., and Fry, W. E. 1991. A second worldwide migration and population displacement of Phytophthora infestans. Plant Pathol. 40: 422-430.

65. Sujkowski, L. S., Goodwin, S. B., Dyer, A. T., and Fry, W. E. 1994. Increased genotypic diversity via migration and possible occurrence of sexual reproduction of Phytophthora infestans in Poland. Phytopathology 84:201-207.

66. Swofford, D. L. 2002. PAUP*: Phylogenetic analysis using parsimony (*and other methods). Version 4. Sinauer Associates, Sunderland, MA.

67. Tamietti, G., and Valentino, D. 2001. Physiological characterization of a population of Phytophthora capsici Leon. from northern Italy. J. Plant Pathol. 83:199-205.

68. Tian, D., and Babadoost, M. 2004. Host range of Phytophthora capsici from pumpkin and pathogenicity of isolates. Plant Dis. 88:485-489.
69. Tooley, P. W., Therrien, C. D., and Ritch, D. L. 1989. Mating type, race composition, nuclear DNA content, and isozyme analysis of Peruvian isolates of Phytophthora infestans. Phytopathology 79:478-481.

70. Vos, P., Hogers, R., Bleeker, M., Reijans, M., van der Lee, T., Hornes, M., Frijters, A., Pot, J., Peleman, J., Kuiper, M., and Zabeau, M. 1995. AFLP: A new technique for DNA fingerprinting. Nucleic Acids Res. 23:4407-4414.

71. Walker, S. J., and Bosland, P. W. 1999. Inheritance of Phytophthora root rot and foliar blight resistance in pepper. J. Am. Soc. Hortic. Sci. 124:1418.

72. Weber, G. F. 1932. Blight of peppers in Florida caused by Phytophthora capsici. Phytopathology 22:775-780.

73. Wolfe, M. S., and Finckh, M. R. 1997. Diversity of host resistance within the crop: Effects on host, pathogen and disease. Pages 378-400 in: Resistance of Crop Plants Against Fungi. H. Hartleb, R. Heitefuss, and H. H. Hoppe, eds. Gustav Fischer Verlag, Jena. 